\title{
Emotional Intelligence, Creativity and Academic Achievement of Business Administration Students
}

\section{R. Ademola Olatoye ${ }^{1}$, S.O. Akintunde ${ }^{2}$, M.I. Yakasai ${ }^{3}$}

${ }^{1}$ Department of Science, Technology and Mathematics Education, College of Education, Osun State University, Osogbo, Osun State.

2 Department of Business Administration and Management, Moshood Abiola Polytechnic, Abeokuta, Ogun State.

${ }^{3}$ Faculty of Education, Bayero University, Kano, Kano State.

Nigeria

Correspondence: R. Ademola Olatoye. Department of Science, Technology and Mathematics Education, College of Education, Osun State University, Ipetu-Ijesa Campus, Osogbo, Osun State. Nigeria. E-mail: kingdemola@yahoo.com

(C) Education \& Psychology I+D+i and Editorial EOS (Spain) 


\begin{abstract}
Introduction. This study investigated the extent to which the level of creativity and emotional intelligence influenced the level of academic achievement of Higher National Diploma HND business administration students of Polytechnics in the South Western States of Nigeria.
\end{abstract}

Method. Three instruments; Student Cumulative Grade Point (CGPA) Information Format (SCIF); Wong and Law Emotional Intelligence Scale (WLEIS) and Nicolas Holt Creativity Test (NHCT) were used to collect data on the emotional intelligence, creativity and the academic achievement of a sample of 235 subjects.

Results. There is a very low negative, no significant relationship between creativity and CGPA scores ( $r=-.004, p>.05)$. There was no significant difference between male and female students' academic achievement, creativity and emotional intelligence.

Discussion and Conclusions. An emotionally intelligent student in the Polytechnic system is likely to be creative but not likely to be a high academic achiever. Polytechnic Management should also ensure a Creativity and Emotional Intelligent-friendly school environment.

Keywords: Emotional Intelligence, Creativity, Academic Achievement, Business Administration Students, Polytechnic System.

Received: 03/30/10 Initial Acceptance: 04/07/10 Definitive Acceptance: 07/27/10 


\title{
Inteligencia emocional, creatividad y logro académico en los estudiantes de empresariales
}

\begin{abstract}
Resumen
Introducción. Este estudio investiga la cantidad de influencia del nivel de creatividad e inteligencia emocional en el logro academic de los estudiantes diplomados en empresariales de los polictécnicos de los estados del sudoeste de Nigeria.

Método. Se utilizaron tres instrumentos: Puntuación Acumulada de Grado del Estudiante (PAGE); Escala de Inteligencia Emocional de Wong y Law (WLEIS) y Test de Creatividad de Nicolas Holt (NHCT). Los instrumentos se utilizaron para obtener datos de inteligencia emocional, creatividad y logro academic de una muestra de 235 participantes.
\end{abstract}

Resultados. Existe una baja relación negative, no significativa, entre creatividad y puntuación de grado $(r=-.004, p>.05)$. No se encuentran diferencias significativas entre hombres y mujeres en relación al rendimiento académico, creatividad e inteligencia emocional.

Discusión y conclusiones. Un estudiante de politécnico emocionalmente inteligente aparece como creativo aunque no necesariamente con buen logro académico. Los gestores de los politécnicos deberían asegurarse de crear un ambiente creativo y adecuado.

Palabras Clave: Inteligencia emocional; creatividad; logro académico; estudiantes de empresariales; politécnicos.

Recibido: 30/03/10 Aceptación Inicial: 07/04/10 Aceptación Definitiva: 27/07/10 


\section{Introduction}

In today's highly competitive world, education plays a key role in the success and prosperity of individuals (Amusan, 2006). In the formal education sector, academic achievement is the main measure of the level of education attained, which is meant to achieve the curriculum objective of success and prosperity as defined by the society. By implication, academic achievement distinguishes between students and predicts their success at work. Educators have therefore been interested in those factors which influence or are associated with academic achievement (Bakare, 1979; Hassan, 2001; Onabamiro, Owoyele, Toyobo, \& Majekodunmi, 2007). Also, higher education across the world is striving to produce graduates that will be self-reliant. Studying business administration offers students opportunity to develop skills, abilities and understanding necessary to enter and progress in particular business occupations. Business administration prepares students for job competence, occupational intelligence and work adjustment. Unlinfun (1986), Aina (1991) and Adeola (2006) opined that skills acquired through business education can lead to individual's economic survival and self-employment. Student exposure to business skills according to Malbary (1999) is to create a pool of men and women of character and competence, people who are balanced in their physical, emotional and spiritual well-being and who will be effective in the design and implementation of national development strategies. A good business administrator therefore should be emotionally intelligent, creative and innovative.

Bar-On (1996) explained that emotional intelligence is one's ability to deal successfully with other people and with one's feelings. Hence, emotional intelligence involves one's awareness of one's feelings and the feelings of others and the capacity to utilize this in directing one's behaviours. Akinboye (2003) defined emotional intelligence as a set of noncognitive abilities that influence human ability to success in life and at work place. He stressed that for human beings to be successful in life and workplace, they need the skills of emotional intelligence which manifest in attributes such as honesty, energy, trust, integrity, intuition, imagination, resilience, purpose, commitment, influence, motivation, sensitivity, humour, courage, conscience and humility. Ciarrochi, Chan and Caputi (2000) also found that emotional intelligence is positively correlated with such variables as empathy, verbal intelligence, extroversion, openness to feelings, self-esteem and life satisfaction. Emotional intelligence can be conceptualized as a set of acquired skills and competencies that predict positive outcome at home with one's family, in school and at work. 
Many studies on emotional intelligence use work-related factors as dependent variable. For example, Moss (2001) found positive relationship between emotional intelligence and leadership style. Duckett (2002) linked emotional intelligence with increased employees' cooperation, motivation, productivity and increased profit. There is need for research studies that that will link emotional intelligence with student learning outcomes. This is to enable students, teachers and counsellors to know the place of emotional intelligence in teaching, learning and counseling. One good thing about emotional intelligence is that it can be learned. Duckett (2002) asserted that emotional intelligence can be learned at any stage in life. Animasahun (2007) also found that teaching prison inmates' emotional intelligence raised their positive life skills.

Earlier studies have indicated intelligence (narrowly defined as intelligence quotient) as the key factor influencing academic achievement (Douglas, 2006). It was believed that high Intelligence Quotient or strong scientific mind is the main measure of academic success (AbiSamra, 2000). This belief had implications for curriculum design, teaching, and examining and research efforts. Literatures show that, for many years, the study of intelligence, as a predictor of success, focused mainly on the adaptive use of cognition (Piaget, 1972). Also our classrooms tend to be dominated by approaches that emphasize principles, facts, theories, generalization, and memorization associated with narrow specialization at the expense of generic skills, which promote originality, and social skills such as creativity and emotional intelligence (Gardner, 1983). However, theories like the Multiple Intelligences theory (Gardner, 1983); the Emotional Intelligence theory (Goleman, 1995; Mayer,Casuro \& Salovey, 1999); Triavehic theory, (Sternberg, 1985) now suggest that success depend on several intelligences. Sternberg (1985), for instance, proposes that intelligence consists of three main parts:

[a] Analytical intelligence (reasoning and processing of information or I.Q) which is the cognitive or intellective element

[b] Creative intelligence (creativity), which is a non-cognitive/intellective element.

[c] Practical intelligence (day-to-day interpersonal relationship such as in the concept of emotional intelligence) - a non-cognitive/intellective element.

The inference of relevance to this study from the above is that, the three; though distinguishable components of intelligence are interrelated and together (not just I.Q.) affect academic achievement. Schutte and collaborators (1998) emphasized that, even though emotions are at the core of Salovey and Mayer (1990) model, it encompasses social and cognitive func- 
tions. Cooper and Sawaf (1997) model of emotional intelligence (E.I) contains "emotional alchemy" which includes the ability to spark creativity. One of the conclusions reached in the Barton, Delman, and Cattell, (1972) studies was that I.Q. (reasoning capacity) together with the personality factors predicted achievement in all areas. Such conclusions, according to AbiSamra (2000) have led to the shift of the center of research concern to whole-child (Learner), not only the reasoning capacities, but also creativity, emotional intelligence and interpersonal skills in accounting for child academic success.

Research has also shown that emotional intelligence-based competences are learned abilities and they improve with age (Click, 2002). Click (2002) did not find significant difference between emotional intelligence of male and female respondents though females had higher E.I. score than males. Also, Prieto, Ferrandiz, Ferrando, Sainz, Bermejo and Hernandez (2008) reported gender difference in E.I scores with female students scoring higher than their male counterparts. However, Adeyemo (2004) while reporting pattern of E.I among counselling psychology students in a Nigerian University found no significant between male and female students. Similarly, Ogunyemi (2008) investigated the effects of provocation and emotional mastery programmes on fostering emotional intelligence of Nigerian adolescents. The study aimed to establish whether gender will moderate the effects of the two techniques on emotional intelligence skills of adolescents. Gender was found not to have any significant effect on participants' levels of emotional intelligence. In another study on E.I of Senior Secondary School students in Nigeria, Mabekoje and Ogunyemi (2003) reported no gender difference in E.I scores. Still on gender difference in intelligence, Naderi, Abdullah, Tegku and Aizan (2008) reported no significance difference between male and female students.

An even more immediate concern in this study is that, in the last ten years, attention has further shifted to generic skills like creativity and emotional intelligence, believed to be better predictors of success (Obanya, 2003). In fact, many studies (Goleman, 1995; Hemphill, 2004; Salovey \& Mayer, 1990) are now pointing to the fact that creativity and emotional intelligence promote success more than the general intelligence. Goleman, (1995) argued that I.Q contributes only about $20 \%$ of life success. This implies that the remaining $80 \%$ of such success is accounted for by other aspects of intelligence as personality traits, E.I and Creativity. This suggests that E.I and creativity can be good predictors of academic achievement and if taught and or enhanced could positively affect academic achievement in our schools. However, the simplicity of this suggestion is complicated by the problem of the appropriateness 
(explicitly) of the construct and context of the concepts under investigation. What is the definition of the creativity and or emotional intelligence, which influence academic achievement, and in what context? For example, O'Hara and Sternberg (1999) opined that creativity and intelligence are outcomes of the same cognitive process. To him this process is called creativity when it produces something novel. However, Barron and Guilford (1996) and Wallach and Kogan (1998) reported that correlations between intelligence, (narrowly defined as I.Q) and creativity are low enough to treat them as distinct concepts. He however found that even this low correlation is non-existence in people with I.Qs over120.

Creativity is fundamental to self-reliance, the more self-reliant a person becomes, the better the quality of his/her life, family, community and society at large. Creativity enables human beings to get the most out of life experiences and resources. Creativity produces actionable ideas, new concepts, new designs and new opportunities while innovation adds values to the new products. According to Akinboye (2003), without creativity, a person is not able to access the fullness of information and resources available but is locked up in old habits, structures, patterns, concepts and perceptions. This is why creativity, generative perception, constructive and design thinking plus innovation should form the basis of any education for sustainable development. Sternberg and Lubart (1996) described creativity as the confluence of intellectual activity, knowledge, motivation, thinking styles, personality and environment. Contrary to findings in this study, creativity should be related to intellectual activity and knowledge. The problem with our educational system is that students are not taught in a way that enhances creative thinking and the assessment procedures do not reward creativity. This is a serious challenge to our educational system especially the polytechnic education that should encourage exposure to technical skills which can be enhanced through creative thinking.

According to Nwosu (2004), creativity cannot be created but it can be nurtured or cultivated and it can also be destroyed. When a study reports that there is no significant relationship between creativity and achievement, there is likely to be a problem in such a system. Gardiner (1980) and Songer, Lee and Kam (2002) are of the opinion that all the classrooms should be a modeled garden. The teacher is the gardener who needs to cultivate students' potential so that they will grow into creative adults. Cronin (1989) asserted that though the importance of creativity is universally recognized, its cultivation in our classrooms is paradoxi- 
cally neglected. Bartel (2001) asserted that creativity has been stifled in many children. The need for lecturers in polytechnic to teach creatively cannot therefore be overemphasised.

Creativity, on the other hand, can also be closely related with E.I. For example, Akinboye (2003) opines that Creativity is tied to emotions which both give it power and make it challenging. This is probably why anytime people need to be creative; they tend to be in an emotional state. Goleman (1998) asserted that people with high E.I skills calm and clear their minds quickly and easily open the way for insight, intuitive and creative ideas. He concluded that E.I is a master aptitude and a capacity that profoundly affects all other abilities, either facilitating or interfering with them. Van der Zee, Schake and Thijs, (2002) affirmed that the currently available empirical evidences show clearly that E.I does not have significant relationship with cognitive ability and academic performance. They admonished that any investigation of the potential effect of E.I on academic achievement must be pursued in a specific context.

Against this background is the fact that most of the related studies are outside Africa. Those that were conducted in Africa like Aremu (2006) have concentrated on the influence of Emotional Intelligence on workplace success, rather than on academic success that is the concern in this study. Those that focused on academic achievement did so in such a narrow context that cannot support confident generalization. For example, few studies have been conducted among non-traditional college students (Drago, 2004) or at secondary level (Aremu. Tella and Tella, 2006) and hence have limited applicability. This is apart from the fact that serious research endeavours, investigating the link between emotional intelligence, creativity and academic achievement in Nigeria are very scanty and or unreported.

As a result, one cannot assert concerning the influence of these traits (emotional intelligence and creativity) or the direction of their influences on academic achievement in Nigeria with sufficient certainty. Consequently, this question and the debate on the desirability of teaching these skills as a strategy for improving students' academic achievement remain unresolved scientifically. In the light of the above, this study sought to determine the relative and combined influences of emotional intelligence and creativity on the academic achievement of students in selected polytechnics in Ogun, Oyo and Lagos States, Southwest of Nigeria. 


\section{Research Questions}

The following questions were generated to guide the study:

1. What is the composite contribution of creativity and emotional intelligence of business administration students of polytechnics to their academic achievement?

2. What is the relative contribution of emotional intelligence of business administration students of polytechnics to their academic achievement?

3. What is the relative contribution of creativity and of business administration students of polytechnics to their academic achievement?

4. What is the relationship between academic achievement of students and their respective levels of emotional intelligence and creativity?

5. Is there any significant difference between male and female student (i) emotional intelligence and (ii) creativity (iii) academic achievement?

\section{Method}

\section{Participants}

The target population for this study consists of all the current final year, Higher National Diploma (HND) students of Business Administration of Polytechnics in Ogun, Lagos and Oyo states, South West of Nigeria. The sample for the study was two hundred and thirty five (235) final year students on a Business Administration (HND) programme in four Polytechnics in the Southwest of Nigeria. The four Polytechnics were selected, using purposive technique; two are Federal while two are state Polytechnics. However, simple random sampling technique was used to select 60 final year HND business administration students in each of the selected Polytechnics. The mean age is 23 , the range is $18-33$, and standard deviation is 6.2. All the selected polytechnics are in urban centres. One hundred and twenty students are from state-owned polytechnics while the same number are from the federal polytechnics, 113 are males while 122 are females.

\section{Instruments}


The under listed three instruments were used for collecting data for this study:

[1] Student Cumulative Grade Point (CGPA) Information Format (SCIF)-attached as appendix I

[2] Wong and Law Emotional Intelligence Scale (WLEIS) attached as appendix II

[3] Nicolas Holt Creativity Test (NHCT) - attached as appendix III

\section{(1) Student Cumulative Grade Point (CGPA) Information Format (SCIF)}

The SCIF was designed by the researcher to collect data about the CGPA, matriculation number, school and gender of students. The CGPA was used as a criterion for academic success of the students.

\section{(2) Wong and Law Emotional Intelligence Scale (WLEIS)}

WLEIS is a16-item self-report scale developed and validated Law and Wong (2002) based on Davies (1998) four-dimensional definition of emotional intelligence. It assesses emotional intelligence competences in the four areas as follows:

Table 1. Competence Areas and Measuring Items

\begin{tabular}{ccc}
\hline S/N & Area of competence & No of measuring test items \\
\hline 1 & Self-Emotional Appraisal (SEA) & Test Item numbers 1-4 \\
2 & Others-Emotions Appraisal (OEA) & Test Item numbers 5-8 \\
3 & Use of Emotion (UOE) & Test Item numbers 9-12 \\
4. & Regulation of Emotion (ROE) & Test Item numbers 13-16 \\
\hline
\end{tabular}

This scale was preferred for the following reasons:

[1] It positively built on Mayer, Caruso, Salovey (1999) Emotional Intelligence Test (MSCEIT) that was regarded as being among the best scales (Abi-Samra, 2000);

[2] It contains less number of items. This would minimize the problem of respondents' boredom and impatience usually associated with administering this type of instrument when they are lengthy. This is especially so in respect of students who do not see the exercise as a requirement of their examination success.

[3] Its construct and criterion validity have been confirmed in the Law and Wong (2002).

The reliability of the instruments was sought through a test re-test method of two weeks interval. The researcher administered 30 copies of the questionnaire to students of Moshood 
Abiola Polytechnic, Abeokuta. This Polytechnic was not included in the major study. Reliability co-efficient of 0.85 was obtained.

\section{Nicolas Holt Creativity Test (NHCT)}

NHCT is a twenty-nine (29)-item instrument, developed by Nicolas Holt to test the level of creativity of persons in the areas of fluency, originality, flexibility and elaboration of traits, among others.

The validity of the instruments was sought by distributing the draft copies of the questionnaires (WLEIS and NHCT) to experts in item construction for their criticism and suggestions. The experts' comments/suggestions were incorporated into the final draft of the instruments.

The reliability of the instruments was sought through a test re-test method of two weeks interval. The researcher administered 30 copies of the questionnaire to students of Moshood Abiola Polytechnic, Abeokuta. Reliability co-efficient of 0.88 was obtained for NHCT.

\section{Procedure}

The permission of the Heads of department of the departments of Business Administration and Management of the selected Polytechnics to use the students were sought and obtained. The assistance of the class coordinators and, in some cases, the H.O.D, were obtained in addressing the students to elicit their cooperation and in administering the instruments Meeting of the sixty (60) randomly selected students in each of the of the institutions was arranged for the administration of the WLEIS and NHCT instruments. This took place just before their scheduled regular classes with the consent of the affected lecturers. The questionnaires were designed such that it should not last for more than twenty minutes each for students at that level of education to complete. The researchers ensured that either the Head of department or the Class Coordinator was physically present with them at the time of administration of the questionnaires. The respondents were assured of the confidentiality of their responses and the importance of their role. They were given opportunity to clarify necessary issues. These were done with a view to enhance response rate and reduce anxiety and subjectivity, which may interfere with the results of the study. 
Data on the students CGPA were collected from the business administration departments of the Institutions, using the SCIF format, described above. The rate of return of questionnaires was $100 \%$. In other words, all the questionnaires were completed and returned. However, the CGPA of 5 out of 240 respondents could not be found. Data analysis was therefore based on 235 students.

The WLEIS and NHCT instruments were designed and scored on a 5-point Likert format type continuum scale ranging from " 1 " to " 5 ":

- " 1 " represents "not so true of me" as we assume that everyone is emotionally intelligent and creative in one-way or the other.

- “3" represents "averagely true of me" and a standard (average) for determining scores that are a below or above average. (i.e. low or high in the variable being measured).

- " 5 " represents fully represents me; in that order.

CGPA data collected through SCIF was classified to show different levels of academic achievement; ranging from 4.00, representing Distinction, to less than 1, representing very poor. This is the grading system approved by the National Board for Technical Education (NBTE) that regulates academic standards in all the polytechnics in Nigeria.

The scores of the students on the three variables were combined and compared to show the overall pattern as well as pattern by schools and by gender of respondents.

\section{Design and Statistical Analysis}

In the study, the independent variables (creativity and emotional intelligence of Polytechnic students) and the dependent variable (academic achievement) have already occurred. We only attempt to identify and compare the variables (without manipulating them) for the purpose of making inferences about their relationship. Therefore Ex-post-facto research design was adopted to find out and describe the extent to which the level of creativity and emotional intelligence influenced the level of academic achievement of HNDII business administration students of Polytechnics in the South West of Nigeria. Many scholars agreed that Ex-post-facto design is the best design for collecting data on variables that have already occurred. 
The researchers compared the level of Academic Achievement with the level of Emotional Intelligence and Creativity of each student to determine the existence and nature of the relationship between the variables, using Statistical Package for Social Sciences (SPSS) version 13.0. Multiple Regression analysis was used to answer research questions 1 and 2. Pearson Product Moment Correlation was used to answer research question 3, while Student t-test was used to answer research questions 4 and 5. All the research questions generated for this study were tested at 0.05 alpha level using a two-tailed test.

\section{Results}

Research Question 1. What is the composite contribution of creativity and emotional intelligence of business administration students of polytechnics to their academic achievement?

Table 2. Combined influence of creativity and Emotional Intelligence on students' academic achievement.

\begin{tabular}{|c|c|c|c|c|c|c|}
\hline \multicolumn{7}{|c|}{$\begin{array}{l}\text { Multiple } \mathrm{R}=.192 \\
\mathrm{R} \text { square }=.037 \\
\text { Adjusted R. square }=.029 \\
\text { Stdd Error }=.3462\end{array}$} \\
\hline Model & Sum of square & Df & Mean square & $\mathrm{F}$ & $\mathrm{p}$ & Remark \\
\hline Regression & 1.063 & 2 & .0531 & 4.43 & .013 & Significant \\
\hline Residual & 27.814 & 232 & .120 & & & \\
\hline Total & 28.877 & 234 & & & & \\
\hline
\end{tabular}

Table 2 shows that the combination of emotional intelligence and creativity in predicting the academic achievement of students, yielded a coefficient of multiple regression of .192, a multiple R square of .037 and an Adjusted R square of .029.This means that E.I and Creativity combined together to significantly influence the academic achievement of the students.

The two independent variables account for $3.7 \%$ of the total variance in students' academic achievement. The table also shows that the analysis of variance for the multiple regression data produced an $\mathrm{F}$ ratio of 4.43 which is significant at .05. This indicates that the effectiveness of the independent variables in predicting the academic achievement of students could not have been due to chance. We can then conclude that the two factors are relevant in predicting and improving the academic achievement of students. 
Research Question 2: What is the relative contribution of emotional intelligence of business administration students of polytechnics to their academic achievement?

Table 3. Influence of Emotional Intelligence on Students' Academic Achievement

\begin{tabular}{|c|c|c|c|c|c|c|}
\hline \multicolumn{7}{|c|}{$\begin{array}{l}\mathrm{R}=.178 \\
\mathrm{R}^{2}=.032 \\
\text { Adjusted } \mathrm{R}^{2}=.032 \\
\text { Stdd Error }=.3464\end{array}$} \\
\hline & Sum of square & $\mathrm{df}$ & Mean square & $\mathrm{F}$ & $\mathrm{p}$ & Remark \\
\hline Regression & 918 & 1 & .918 & 7.648 & .006 & Significant \\
\hline Residual & 27.959 & 233 & .120 & & & \\
\hline Total & 28.877 & 234 & & & & \\
\hline
\end{tabular}

Table 3 shows that E.I significantly influences academic achievement of students ( $R$ Square $=.032, \mathrm{p}<.05)$. E.I. accounts for $3.2 \%$ of the total variance in students' achievement.

Research Question 3: What is the relative contribution of creativity and of business administration students of polytechnics to their academic achievement?

Table 4. Relative Contribution of Creativity of students' to Academic Achievement

\begin{tabular}{lccccc}
\hline $\mathrm{R}=.04$ \\
$\mathrm{R}^{2}=.000$ \\
Adjusted $\mathrm{R}^{2}=-.004$ \\
Stdd Error $=.3520$ \\
\hline \multicolumn{7}{c}{ Sum of square } & df & Mean square & $\mathrm{F}$ & $\mathrm{p}$ \\
\hline Regression & 4.9150 & 1 & $4915 \mathrm{E} .04$ & .004 & .950 \\
Residual & 28.876 & 233 & .124 & & \\
Total & 28.877 & 234 & & & \\
\hline
\end{tabular}

Table 4 shows that creativity does not significantly predict the academic achievement of students. Creativity does not account for any variance in students' achievement as measured by their CGPA.

Research Question 4: What is the relationship between academic achievement of students and their respective levels of emotional intelligence and creativity? 
In table 5, there is a significant positive relationship between student level of creativity and emotional intelligence $(\mathrm{r}=+.389, \mathrm{p}<.05)$. Thus, the higher a student level of creativity, the higher the E.I. Also, the higher the student level of E.I., the higher the level of creativity. However, there is negative insignificant relationship between E.I. and CGPA scores $(r=-.178$, $\mathrm{p}>.05)$. Though not in a significant proportion, still the higher the emotional intelligence the lower the CGPA scores. Similarly, there is negative insignificant relationship between creativity and CGPA scores( $r=-.004, \mathrm{p}>.05)$; also, though in a very insignificant the higher the level of creativity the lower the CGPA scores. This suggests that an emotionally intelligent person is likely to be creative. Both emotionally intelligent as well as creative persons are not likely to be high academic achievers.

Table 5. Correlation Matrix of E.I Creativity and academic achievement of students

\begin{tabular}{lccc}
\hline \multicolumn{1}{c}{ Variables } & E.I & Creativity & Academic Achievement \\
\hline Emotional Intelligence(E.I.) & 1.000 & & \\
Creativity & $+.389 *$ & 1.000 & \\
Academic Achievement & -.178 & -.004 & 1.000 \\
*Significant $(\mathrm{p}<0.05)$ & & &
\end{tabular}

Research Question 5: Is there any significant difference between male and female student (i) emotional intelligence and (ii) creativity (iii) academic achievement?

Table 6 shows that there is no significant difference between male and female student Emotional Intelligence, Creativity and academic achievement is greater .05 . This shows that emotional intelligence, creativity and academic achievement are not sensitive to gender.

Table 6. Comparison of Emotional Intelligence, Creativity and Academic Achievement of Male and Female students

\begin{tabular}{lcccccccc} 
& Gender & $\mathrm{N}$ & Mean & Std. Dev. & Std error & $\mathrm{df}$ & $\mathrm{t}$ & $\mathrm{p}$ \\
\hline \multirow{2}{*}{ E. I. } & Male & 113 & 63.628 & 7.695 & .7239 & & & \\
& Female & 122 & 62.183 & 8.267 & .7546 & 233 & 1.379 & .169 \\
\multirow{2}{*}{ Creativity } & Male & 113 & 99.018 & 12.561 & 1.182 & & & \\
& Female & 122 & 98.208 & 12.007 & 1.0096 & 233 & .503 & .616 \\
\multirow{2}{*}{ Academic Achievement. } & Male & 113 & 2.68 .0 & .358 & 3.365 & 233 & .175 & .861 \\
& Female & 122 & 2.688 & .348 & 3.174 & 233 & \\
\hline
\end{tabular}




\section{Discussion and Conclusions}

The study established a direct positive relationship between emotional intelligence and creativity. This implies that an emotionally intelligence student is likely to be creative. This is in line with the work of Cooper and Sawaf (1997) and Akinboye (2003). Infact, Adeboye (2003) posited that anytime people need to be creative, they tend to be in an emotional state. Secondly, the study indicates that there is negative relationship between emotional intelligence and academic achievement. Also, creativity simply does not significantly predict academic achievement of students in the Polytechnic system.

The inverse or negative relationship between emotional intelligence and academic achievement is surprising. This is because, it contradicts the findings of many researchers such as Nelson and Low (2003) and Petrides et al (2004) who reported significant relationship between emotional and academic achievement. Since emotional intelligence is expected to facilitate students' ability to cope with academic demands, one suspects the mode of measuring student achievement may not encourage creativity. In this case very creative student may not really have advantage over the less creative ones. The teaching methods and environment might also be inhibiting the creative and emotional intelligence potentials of students in these institutions; instead of facilitating them. The possibility of this is buttressed by studies (Gardner, 1983; Carmeli \& Josman, 2006) which found that our classrooms tend to be dominated by approaches that emphasize narrow specialization at the expense of generic skills, which promote originality, and social skills such as creativity and emotional intelligence. This points to anomaly in our school curriculum and or the method of course delivery. These reasons may provide explanation for the inverse relationship between emotional intelligence and academic achievements found in this study.

The no-relationship between creativity and academic achievement of students in this study agrees with Xiaoxia (1999) who reports that creativity is rarely related to academic achievement. Given the parental and teaching practices in many homes and schools in Nigeria, one is not surprised by the result of this study. Hassan (2001) also alluded to the fact that the inherited pattern of assessment in Nigeria is usually restricted to one (cognitive) of the aspects of learning outcomes at the end of teaching-learning process and does not encourage innovativeness and creativity in the teacher and the learner. It is therefore not surprising that many known creative celebrities like Darwin, the Nigeria's Mathematics genius, Professor 
Chike Obi, Professor Wole Soyinka (a Nobel Laureate) and Late Chief Gani Fawehimi (an internationally acclaimed human right activist and lawyer), among others, were not known to be high academic achievers in their school days. However, an emotionally intelligent person is likely to be creative, but emotionally intelligent as well as creative persons are not likely to be high academic achievers. Creativity and emotional intelligence have been identified as key requirements of entrepreneurship which has been adopted in Nigeria as a major curriculum objective. This therefore calls for a review of the curriculum, teaching and evaluation strategies in line with the need for emotional intelligence and creativity as tools of promoting entrepreneurship in Nigeria.

In this study, emotional intelligence has negative though insignificant relationship with business administration students' academic achievement as measured by their cumulative Grade Point Average (CGPA). The result can be seen from two perspectives. First, possibly the grading or assessment of students in school does not test emotional intelligence. Therefore, one may not necessarily be highly emotionally intelligent to do well in school. Second, the scope of emotional intelligence is so broad that, it takes more than paper-andpencil assessment to determine who is emotionally intelligent. Many aspects of emotional intelligence such as sensitivity, courage, influence, resilience, intuition, integrity and trust identified by Akinboye (2003) cannot be easily measured through common conventional tests in the classroom. There is therefore the need to carry out more studies on emotional intelligence in Nigeria using students' achievement as the dependent variable.

Based on the popular stereotype, one expects that female would be more emotionally intelligent and creative but lower in academic achievement than male. The present study showed that there is no significant difference in the emotional intelligence, creativity and academic achievement of male and female students. These findings showed that these traits are equally distributed among males and females contrary to the popular stereotypes.

The picture emerging from this study is that emotional intelligence in strongly associated with creativity but the two traits are negatively related with academic achievement of students in the Polytechnic System. The significant relationship between E.I and creativity is expected and also corroborates the work of many other researchers. However, the negative relationship between E.I and academic achievement and also between creativity and academic achievement are surprising. This points to an anomaly in the school curriculum and or the 
method of course delivery. Such a situation negates the objectives of the Polytechnic system which is expected to produce technological and entrepreneurial education. Creativity and emotional intelligence are required for academic achievement which the present polytechnic system probably does not measure or emphasise.

Based on the findings, it is recommended that emotional intelligence and Creativity should be taught, facilitated and assessed as a separate course, in the educational system. Teachers have to be trained to know and adopt methods which foster complementary values by fostering Creativity and Emotional Intelligence-friendly School Environment. It is therefore, important that school authorities manage the students and teachers in a way that encourage the culture of creativity and emotional intelligence values. These values should be recognized and rewarded. Learning environment should be rich in team spirit, tolerance of the genuine mistake caused by creative predisposition and emotional sensitivity.

\section{References}

Abi-Samra, N. (2000). Relationship between Emotional Intelligence and Academic Achievements in Eleventh Graders. Auburn: Auburn University at Montgomary.

Adeola, K. (2006). Information Technology and Enhancement of Business Education. In O. A. Oyedeji \& B. Ogunyemi (Eds). Perspectives in Nigeria Education: Issues of the New Millenium (232-340). Ago-Iwoye: Faculty of Education Olabisi Onabanjo of University.

Adeyemo, O. A. (2004). Patterns of Emotional Intelligence among counseling psychology students in a Nigerian University. Sokoto Educational Review, 7, 194-203.

Aina, O. (1991). Technical and vocational training as a strategy for technical development. The Nigeria Teacher Today, 2(1), 40-45.

Akinboye J.O. (2003). Creativity, Innovation and Success. Ibadan: Sterling Horden Publishers (Nig) Ltd.

Akinboye, J. O. (2003). Creativity, Innovation and Success. Ibadan: Stirling-Horden Publishers Nigeria Limited.

Amusan, O. (2006). Teacher and the Universal Basic Education: Ogun Update, Bi-monthly Newsletter of Ogun State Public Service, 5, 8. October 2006. 
Animasahun, R. A. (2007). Effectiveness of Emotional Intelligence Education in Enhancing Positive Life Skills of Nigerian Prison Inmates. In: I. A. Nwazuoke, E. A. Okediran \& O. A. Moronkola (Eds.) Education for Social Transformation. (123-130). Ibadan: Faculty of Education, University of Ibadan.

Aremu, A.O (2006). A Confluence of Credentialing, career experience, self-efficacy, emotional intelligence, and motivation on career commitment of young police in Ibadan, Nigeria. International Journal of Police Strategies \& management, 28(4).77-85.

Aremu, A.O,Tella,A\&Tella, A. (2006). Relationships among Emotional Intelligence, Parental Involvement and Academic Achievement of Secondary School Students in Ibadan. Http://www.Usca.Edu/essays/vol.1.

Bakare C.G.M. (1979). Cumulative cognitive deficiency syndrome among African Children. Inaugural Lecture, University of Ibadan, Nigeria.

Bar-On, R. (1996). Emotional Quotient Inventory: A measure of Emotional Intelligence. Technical Manual, Toronto: Multi-Health Systems.

Barron, E. \& Guilford,R. (1996). Emotional intelligence and academic intelligence in career and life success. Paper presented at the Annual Convention of the American Psychological Society, San Francisco, CA.

Bartel, M. (2001). Ways not to kill classroom creativity. Available: www. Goshenedu/art/ed/creativitykiller.html Retrieved $2^{\text {nd }}$ December, 2005.

Barton, K., Delman, T.E., \& Cattell, R.B. (1972). Personality and I.Q measures as predictors of school achievement. Journal of Educational Psychology, 63(4), 398-404.

Carmeli, A., \& Josman, Z.E. (2006). The relationship among emotional intelligence, task performance, and organizational citizenship behaviors, Human Performance, 19(4), 40319.

Ciarrochi, J. U., Chan, A.Y.C., Caputi, P. (2000). A critical evaluation of the emotional intelligence construct. Personality and Individual Differences, 28, 539 - 561.

Click, H. S. (2002). An exploration of emotional intelligence scores among students in educational administration programme. Unpublished Ph.D Thesis, East Tennessee State University.

Cooper, R.K., \& Sawaf, A. (1997). Executive E.O: Emotional Intelligence in leadership \& organizations, NY: Grossat/Putram.

Cronin, L. L. (1989). Creativity in the Science Classroom: Why it is as essential as a microscope? The Science Teacher, 56(2), 35-36.

Douglas, K. D. (2006). Intelligence Microsoft@Encarta; 1993-2005 Microsoft Corporation. 
Drago, J.M. (2004). Relationship between Emotional Intelligence and Academic Achievement in Non-Traditional College Students. Consortium for research on emotional Intelligence in Organisation U.S.A.

Duckett, M. (2002). General intelligence, average intelligence and emotional intelligence. Handbook of Human Intelligence, New York: Cambridge University Press.

Gardiner, W. L. (1980). The psychology of teaching. Monterey: CA Books/Cole.

Gardner, H. (1983). Frames of mind; the theory of multiple intelligences, N.Y: Basic Books.

Goleman, D. (1995). Emotional Intelligence:Why it can matter more than I.Q. London, Bloomsburg.

Goleman, D. (1998). What makes a Leader? (HBR, Nov/Dec 1998 pg 93) USA.

Hassan, T. (2001). Students' Performance and Certification. Paper in Proceedings of the $10^{\text {th }}$ Annual Congress of the Nigerian Academy of Education held in the University of Jos, 12 - 16 Nov, 2001.

Hemphill, J.K. (2004). Job Description for Executives. Harvard Business Review, 37(5), 5565.Http//www.healthline.com.gatecontent.

Law, K. S \& Wong, C. (2002). The Construct and Criterion Validity of Emotional Intelligence and it Potential utility for Management Studies. Journal of Applied Psychology, 89(3), 483-496.

Mabekoje, S. O. \& Ogunyemi, B. (2003). Emotional intelligence within the classroom context: The influence of gender and sociometric status. Journal of Research in Counselling Psychology, 9(1), 94-103.

Malbary, N. H. (1999). Principles and Problems of Business Education Ohio: Southwestern Publishing Company.

Mayer J., Caruso, D. \& Salovey, P. (1999). Emotional Intelligence meets Traditional Standard for Intelligence. Intelligence, 27(1), 21-19.

Moss, M. T. (2001). Emotional determinants in health care executive management styles. Unpublished PhD. Dissertation. Medical University of South Carolina. College of Health Professionals.

Naderi, Abdullah, R. \& Tengku-Aizab, H. (2008). Male versus Female intelligence among undergraduate students: Does gender Matter? Asian Journal of Scientific Research, $7(2), 88-97$.

Nelson, D., \& Low, G. (2003). Emotional intelligence: Achieving academic and career excellence. Upper Saddle River, NJ: Prentice-Hall. 
Nwosu, A. A. (2004). Teachers' awareness of creativity-related behaviours in the science classroom: Implication for national development. Journal of Science Teachers Association of Nigeria, 39(1\&2), $22-30$.

O’Hara, L.A, \& Sternberg, R.J. (1999). Creativity and Intelligence. In E.D. Sternberg, R.J.(Eds) Handbook of Creativity, Cambridge: Cambridge University Press.

Obanya, P.A.I. (2003). Reeducating All Nigerians. Public Lecture Series of Oyo State College of Education, Oyo, Nigeria, Numbers 12 \& 13. Published by Oyo State College of Education, Oyo, Nigeria,

Ogunyemi, A. O. (2008). Measured effects of provocation and emotional mastery techniques in fostering emotional intelligence among Nigerian adolescents. Electronic Journal of Research in Educational Psychology, 6(2), 281-296.

Onabamiro, A.; Owoyele, J., Toyobo, W., Majekodumi O. (2007). Some Causative Factors as Correlates of Students' Academic Achievement in two Secondary School Core Subjects in Four State Capitals in Nigeria: Implication for Counseling. Journal of Applied Education and Vocational Research, 2(3), 45-52.

Palaniappan, A. K. (2007). Influence of Intelligence on the Relationship between creativity and academic achievement Department of Educational Psychology and Counselling. University of Malaya, Kuala Lumpur, Wilayah Persekutuan, Malaysia.

Penick, J. E. (1992). Teaching for Creativity. In J. Reay and J. George (Eds). Education in Science and Technology for Development: Perspectives for the $21^{\text {st }}$ Century (79-88). Trinidad and Tobago: ASBIT.

Petrides, K.V., Frederickson, N. \& Furnham, A. (2004).The role of trait emotional intelligence in academic performance and deviant behaviour at school. Personality and individual differences. 36(1), 277-293.

Piaget J. (1972). The Psychology of Intelligence. Totowa, NJ: Littlefield Adams.

Prieto, M. D. Ferrandiz, C. Ferrando, M., Sainz, M., Bermejo, R. \& Hernandez, D. (2008). Emotional Intelligence in high-ability students" A comparative study between Spain and England. Electronic Journal of Research in Educational Psychology, 6(2), 297320.

Salovey, P., \& Mayer, J. (1990). Emotional Intelligence. Imagination, Cognition and Personality, $9(3), 185-211$.

Schutte, N. S, Malouff, M. J; Hall, L. E; Haggerty, D. J; Cooper, J. T.; Golden, C. J. \& Dornheim (1998). Development and Validation of a measure of emotional intelligence in Personality and Individual Differences. Oxford: Pergamon Press. 
Songer, N. B., Lee, H. Kam, R. (2002). Technology-Tick Inquiry Science in urban classrooms: What are the barriers to Inquiry pedagogy? Journal of Research in Science Teaching, 39(2), 128-150.

Sternberg R. (1985). Intelligence Applied: Understanding and Increasing your Intellectual Skills, San Diego :Harcourt Grace Jovanovich..

Sternberg, R. \& Lubart, S. (1996). Creativity as the confluence of intellectual activity, knowledge, motivation, thinking styles,U.K.www.elsefier.com/locate/paid. Retrieved on $3 / 12 / 2009$.

Ulinfun, F. (1986). Business Education: A utility Education in a developing economy. Business Education Journal, 1(1), 26 - 34.

Van der Zee, K, Schake, K, L, \& Thijs, M. (2002). The relationship of emotional intelligence with academic intelligence and the big five European Journal of personality, 16, 103125.

Wallach,G. and Kogan, V. (1998).Creativity Encyclopedia,

http://en.wikipedia.org/wiki/creativity.

Wechster, D. (1939). Non-intelligence Factors in General Intelligence. Psychological Bulletin, 37, $444-445$.

Xiaoxia, A.I. (1999). Creativity and Academic Achievement: An Investigation of Gender Differences. Mahwah: Mahwah Publishers.

\section{APPENDIX I \\ STUDENT CGPA INFORMATION FORMAT}

School/Polytechnic:

Department:

\begin{tabular}{|c|c|c|c|}
\hline S/N & MATRIC NO. & SEX & GCPA \\
\hline & & & \\
\hline & & &
\end{tabular}

\begin{tabular}{|l|l|l|l|}
$\cdots$ & $\cdots$ & \\
\hline & & & \\
\hline
\end{tabular}

\section{Signed:}

Date:

HOD/Record Officer 


\section{APPENDIX II}

\section{LAW AND WONG EMOTIONAL INTELLIGENCE SCALE (2002)}

\section{INSTRUCTIONS:}

To what extent would say that you experience or engage in the following activities?

(Please respond by marking ' $x$ ' in appropriate holes, from ' 1 ', indicating 'not much at all' to '5', indicating 'very, very much' in front of each of the under listed activities. Note that there is no right or wrong answer; only what you sincerely believe to be true of you. Also, your response is highly confidential; hence, no name is required).

1. I have a good sense of why I have certain feelings most of the time

2. I have good understanding of my own emotions

3. I really understand what I feel

4. I always know whether or not I am happy

5. I always know my friends' emotions from their behaviour

6. I am a good observer of others' emotions

7. I am sensitive to the feelings and emotions of others

8. I have good understanding of the emotions of people around me

9. I always set goals for myself and then try my best to achieve

10. I always tell myself I am a competent person

11. I am a self-motivating person

12. I would always encourage myself to try my best

13. I am able to control my temper so that I can handle difficulties rationally

14. I am quite capable of controlling my own emotions $\begin{array}{llllll}1 & 2 & 3 & 4 & 5\end{array}$

15. I can always calm down quickly when I am very angry $\begin{array}{lllllll}1 & 2 & 3 & 4 & 5\end{array}$

16. I have good control of my own emotions $\quad \begin{array}{llllll}1 & 2 & 3 & 4 & 5\end{array}$ 


\section{APPENDIX III}

\section{THE CREATIVE COGNITION INVENTORY}

\section{INSRUCTIONS:}

To what extent would say that you experience or engage in the following activities?

(Please respond by marking ' $x$ ' in appropriate holes, from ' 1 ' indicating 'not much at all' to ' 5 ', indicating 'very, very much' in front of each of the under listed activities. Note that there is no right or wrong answer; only what you sincerely believe to be true of you. Also, your response is highly confidential; hence, no name is required).

1. Making discoveries through trial and error

2. Trusting hunches or instincts

3. Ideas arising whilst dreaming

4. Methodical and systematic problem solving

5. Sudden moments of inspiration in waking life

6. Rational, logical thought

7. A sense of communicating with a deeper sense of self

8. The careful selection of ideas

9. Loose, playful, unconstrained thinking

10. Following your intuition

11. Ideas arising as falling asleep or waking up

12. Meditation

13. Paying attention to visual imagery

$\begin{array}{lllll}1 & 2 & 3 & 4 & 5 \\ 1 & 2 & 3 & 4 & 5 \\ 1 & 2 & 3 & 4 & 5 \\ 1 & 2 & 3 & 4 & 5 \\ 1 & 2 & 3 & 4 & 5 \\ 1 & 2 & 3 & 4 & 5 \\ 1 & 2 & 3 & 4 & 5 \\ 1 & 2 & 3 & 4 & 5 \\ 1 & 2 & 3 & 4 & 5 \\ 1 & 2 & 3 & 4 & 5 \\ 1 & 2 & 3 & 4 & 5 \\ 1 & 2 & 3 & 4 & 5 \\ 1 & 2 & 3 & 4 & 5 \\ 1 & 2 & 3 & 4 & 5\end{array}$

14. Experiences of losing track of time when involved in crea- $\begin{array}{llllll}1 & 2 & 3 & 4 & 5\end{array}$ tive work

15. Playing with ideas

16. Luck, chance, 'fortunate accidents'

$\begin{array}{lllll}1 & 2 & 3 & 4 & 5\end{array}$

17. The use of analogy

18. A sense of purpose that seems to come from beyond the self

19. Recombining existing elements in new ways

20. Working with a set goal or outcome in mind

21. A sense of channeling information

22. Paying attention to auditory impressions

23. Day dreaming

24. The release of negative emotions

25. Non-verbal modes of thinking

26. Positive emotions, e.g. joy, excitement, euphoria

27. Paying attention to bodily feelings

28. A sense of communicating with something other

29. A sense of being in tune with nature or the universe 5 5 5 